\title{
The Informational Response of Different Investor Types on Futures Return Fluctuations: Evidence from Taiwan's Index Futures Market
}

\author{
CHEN-CHENG CHIEN, CHUN-NAN CHEN \\ Graduate Institute of Finance \\ National Taiwan University of Science and Technology \\ Taipei City 106335 \\ TAIWAN (R.O.C.)
}

\begin{abstract}
This article examines the price impact of different types of investors' trading activities in the Taiwan index futures market on the market, and explores the information roles of different types of investors. We find the trading volumes of different investors in the index futures market affect futures returns through information. The impact on index futures returns in the current period is small, showing the ability of foreign institutional investors to quickly respond to negative news and obtain information advantages. Further, from the MSE and QLIKE loss functions, individual investors use $\operatorname{EGARCH}(1,1)$, domestic institutional investors TGARCH $(1,1)$, and foreign institutional investors $\operatorname{GARCH}(1,1)$. Further, the imbalance of buy and sell orders is suitable for the fluctuation of futures returns using $\operatorname{EGARCH}(1,1)$.
\end{abstract}

Key-Words: - index futures; return volatility; variance estimation; investment behavior

Received: March 20, 2021. Revised: September 26, 2021. Accepted: October 19, 2021. Published: November 4, 2021.

\section{Introduction}

How information is reflected in asset prices through trading activities is not only a research topic that scholars care about, but also a topic that is of interest to market investors. In recent years, there are still literatures in academic research that have observed a significant correlation between trading activities and subsequent price changes, for example, $[3,23]$. When there is a degree of price shock in market transactions, the informational nature of the price shock caused by such trading activities has further aroused concern. For example, $[15,22,23,24]$ found that the degree of information implicit in open market exchanges is correlated with subsequent changes in asset prices. In other words, the different levels of information among traders in the market should influence the changes in asset prices through trading activities. And by analyzing the price influence of investors' trading activities, we can understand the information role of investors in the market..

Therefore, investment transactions will have a fluctuation impact on asset prices. The question is what is the information that causes such asset price fluctuations. Past researches observed the constituent factors of asset price fluctuations come from market transaction openness [5, 7, 11, 23, 25]. The degrees of information held by investors in the market are different, which affects the volatility of asset prices. Therefore, this article analyzes the volatile nature of asset prices to better understand the information conditions owned by different investors. For instance, [16] pointed out that in the practice of futures trading, rational investors (fundamental monitors) may not be able to react immediately through trading due to factors such as the cost of information acquisition, ability to resolve information, restrictions on trading positions, and restrictions on capital resources for futures-related information, that is, futures prices often respond to information inadequately, causing prices to show a positively correlation. Appropriate positive feedback helps information be quickly incorporated into the price, so it can reduce the positive effect of future prices.

The information holding conditions of different investors are discussed by analyzing the relationship between investors' activities and asset price fluctuations by [4, 6, 23, 24], among others. [24] used the information and liquidity hypotheses to explain the price fluctuations generated by trading activities and judged investors by the continuity of these fluctuations. [24] distinguished investor's information holding conditions as information advantages, being only affected by market liquidity; the former investors were found to satisfy the information hypothesis and the latter follow the liquidity hypothesis.

To fully capture the informational nature of assets, this study considers the longest trading history and the earliest open investment targets of different investors (domestic and foreign) on the 
Taiwan Stock Index Futures. $[15,17,24]$ found that futures transactions of the same underlying asset are more informative than other transactions. Additionally, this study uses the overall market price changes to reflect the market development information because overall market information is usually public and can be obtained by every investor. Therefore, for specific investors, whether they have an information advantage in the index futures market can be used for analysis. In view of this, this study analyzes the impact of the transactions of three different types of investors (i.e., foreign institutional, domestic institutional, and individual investors) on futures prices in the Taiwan index futures market to observe the different investors' trading information content and whether certain investor types of investors can have an information advantage. To this end, we use [24]'s model and hypotheses. The use of investors' buying, selling, and buying and selling order imbalances as proxy variables for trading activities and the fluctuations of real-time index futures prices of different types of investors' trading activities clarify whether the various types of investors have liquidity in the futures market.

Various empirical models on the effects of investor information on asset price fluctuations have been used in the literature. For example, [1] used the simple generalized autoregressive conditional heteroskedasticity $(\mathrm{GARCH})(1,1)$ to describe the fluctuation of asset prices affected by information. Antoniou, Koutmos, and Pericli (2005) captured the heterogeneity of information holding with a noncontrast GARCH model. [10] tested the effects of GARCH, threshold GARCH (TGARCH), and random walk (RW) models on asset price volatility using asset data for Germany, the Netherlands, Spain, Italy, and Sweden. Therefore, this paper not only evaluates the impact of the information conditions of different investors on the fluctuation of asset prices, but also the performance of the various empirical models regarding the fluctuations in the prices of different products through loss functions.

Further, [18] explored the dynamic effects of major stock price returns in the United States. Based on the traditional symmetric GARCH and volatility symmetric TGARCH models, their predictive capabilities for volatility were proven. The traditional symmetric GARCH model also shows that stock price returns have volatility (symmetry), that is, bad news can cause large fluctuations in the market. [9] used a volatility index (VIX), a Nasdaq 100 index, and an ETF to study the implicit volatility in time series. A main model and an intra- day return volatility model were used to predict the volatility of returns. The results showed that the volatility model can reliably predict volatility, and the TGARCH model is superior to the GARCH model, which implies that the return volatility of the ETF is asymmetric. Disperse its non-systematic risk, the GARCH model uses non-systematic risk information, meaning that predicting volatility is worse than using implied volatility, which holds for out-of-sample prediction performance.

[11] compared the prediction performance of the linear $\operatorname{GARCH}(1,1)$ with the nonlinear exponential GARCH (EGARCH) $(1,1)$ model using the monthly returns of seven developing Chinese stock markets. The results show the estimations of $\operatorname{GARCH}(1,1)$ are better than those of $\operatorname{EGARCH}(1,1)$. GonzálezRivera, Lee, and Mishra (2004) compared the stock return volatility predicted by various models through a loss function, and found $\operatorname{EGARCH}(1,1)$ has the best performance, with the performance of each model varying depending on the loss function.

Our empirical results show that the information hypothesis holds for individual investors because in the index futures market, the main source of information for investors is public information. That is, the information advantage of an investor should be based on the ability to quickly respond to or interpret information. Conversely, the trading behaviors of domestic and foreign institutional investors support the liquidity hypothesis but the test results under the different empirical models are inconsistent. This means that the characteristics of the transaction information of individual investors are unstable and have high noise. However, $\operatorname{GARCH}(1,1)$, TGARCH$(1,1)$, and $\operatorname{EGARCH}(1,1)$ are used to estimate the impact of different investors' trading behaviors on the fluctuation of returns on the Taiwan Index futures. The futures buy and sell orders of different investors affect the futures return rate. Under the loss function, individual investors should use $\operatorname{EGARCH}(1,1)$, institutional investors $\operatorname{TGARCH}(1,1)$, and foreign institutional investors $\operatorname{GARCH}(1,1)$. Regardless of investor type, the imbalance of buy and sell orders is suitable for the fluctuation of futures returns, which makes the use EGARCH $(1,1)$ preferable.

The remainder of the paper is organized as follows. Section 2 presents the research method and section 3 the data; further, section 4 summarizes the empirical results, and section 5 concludes the article. 


\section{Method}

\subsection{Return Volatility Estimation Model}

According to the three investor types in the multiparty and short-term Taiwan stock futures transaction data and the application of [24] to estimate the return of Taiwan stock futures for empirical analysis, we analyze the different types of investors' trading activities. The impact of index futures returns is used to clarify whether the various types of investors only provide liquidity in the futures market or are information investors. The investor's buy and sell order imbalance trading volume model is set as follows:

$E_{i, t}=B_{i, t}-S_{i, t}$,

where $E_{i, t}$ is $i$ 's type of investor's order imbalance in $t$, that is, the difference between multi-party and short-term transaction volumes. $B_{i, t}$ is $i$ 's type of investor's purchase order volume in $t$ and $S_{i, t}$ is $i$ type of investor's sell order volume in $t$. The $i$ type of investor can be a foreign or domestic institutional investor or an individual investor.

The calculation of the return on Taiwan stock index futures considers the return on the futures holding period, defined as follows:

$R_{t}=100 \times\left(\ln P_{t}-\ln P_{t-1}\right)$,

where $P_{t}$ represents the futures closing price at time $t$, thereby capturing futures return $R_{t}$ at time $t$.

According to [24], the regression equation for the relationship between the multi-party and short-term transactions of different investors on the futures return rate has the retrospective time controlled to 4 lag periods:

$R_{t}=\alpha_{t}+\lambda_{o} B_{i, t}+\sum_{t=1}^{4} \lambda_{t} B_{i, t-1}+\sum_{t=1}^{4} \eta_{t} S_{i, t-1}+\varepsilon_{i, t}$,

where $\varepsilon_{i, t}$ is the residual value.

In the regression of the effect of the order imbalance on the futures return rate, we use the method of [23] to measure the loss of the purchase order of the $i$ type of investor in the $t$ period and assume the $E_{i, t}$ normalization, that is, $E_{i, t}$ is divides it by the absolute value of the average $E_{i, t} /\left|\overline{E_{l, t}}\right|$. The equation is:

$R_{t}=\alpha_{t}+\gamma_{o} E_{i, t}+\sum_{t=1}^{4} \gamma_{t} E_{i, t-1}+\mu_{i, t}$,

where $\mu_{i, t}$ is the residual value.
Assume all the information in the previous period is expressed $\Omega_{i, t}$ and is considered; then, the residuals of equations (3) and (4) will satisfy:

$\varepsilon_{i, t} \mid \Omega_{i, t} \sim N\left(0, \sigma_{t}\right)$,

$\mu_{i, t} \mid \Omega_{i, t} \sim N\left(0, v_{t}\right)$.

Based on the above model, we construct the following futures return volatility estimation model.

\subsubsection{GARCH Model}

The GARCH model could express (5) and (6) as:

$$
\begin{aligned}
& \sigma_{t}^{2}=\omega_{0}+\sum_{j=1}^{q} \alpha_{j} \varepsilon_{t-j}^{2}+\sum_{j=1}^{p} \beta_{j} \sigma_{t-j}^{2}, \\
& v_{t}^{2}=\omega_{0}+\sum_{j=1}^{q} \alpha_{j} \mu_{t-j}^{2}+\sum_{j=1}^{p} \beta_{j} v_{t-j}^{2},
\end{aligned}
$$

where $\omega_{0}, \alpha_{j}$, and $\beta_{j}$ are unknown vectors and $p$ and $q$ are the steps of the GARCH model process. [2] has suggested that process orders $p$ and $q$ be reduced to 1 to form $\operatorname{GARCH}(1,1)$ :

$$
\begin{aligned}
& \sigma_{t}^{2}=\omega+\alpha \varepsilon_{t-1}^{2}+\beta \sigma_{t-1}^{2}, \\
& v_{t}^{2}=\omega+\alpha \mu_{t-1}^{2}+\beta v_{t-1}^{2} .
\end{aligned}
$$

\subsubsection{TGARCH Model}

Many financial studies have empirically pointed out that good and bad news in the market have a symmetric impact on the return of financing assets, which is also referred to as the leverage effect. It refers to "the direction of the asset's price change is not symmetrical to its fluctuations." For example, when the price of an asset fell in the previous period, the return of the previous period was negative. By increasing the risk of holding the asset, [10] proposed the TGARCH model, which distinguishes the previous market information from positive and negative and includes both into the model at the same time. To determine whether it has a symmetry effect and using virtual variables to capture the different effects of good and bad news, we increase the impact of bad news to fully capture the asymmetric fluctuations caused by the positive and negative impacts. This method is widely used to capture the uncertainty of market volatility, being expressed as follows:

$\sigma_{t}^{2}=\omega+\left(\alpha+\gamma d_{t-1}\right) \varepsilon_{t-1}^{2}+\beta \sigma_{t-1}^{2}, d_{t-1}=\left\{\begin{array}{l}1 \text { if } \varepsilon_{t-1}<0 \\ 0 \text { if } \varepsilon_{t-1} \geq 0\end{array}\right.$,

$v_{t}^{2}=\omega+\left(\alpha+\gamma d_{t-1}\right) \mu_{t-1}^{2}+\beta v_{t-1}^{2}, d_{t-1}=\left\{\begin{array}{l}1 \text { if } \mu_{t-1}<0 \\ 0 \text { if } \mu_{t-1} \geq 0\end{array}\right.$, 
where the good news, $\varepsilon_{t-1} \geq 0\left(\mu_{t-1} \geq 0\right)$, or bad news, $\varepsilon_{t-1}<0\left(\mu_{t-1}<0\right)$, in the previous period have different effects on the current condition change, $\sigma_{t}^{2}\left(v_{t}^{2}\right)$. For good news, $\sigma_{t}^{2}\left(v_{t}^{2}\right)$ has the impact from the previous period's variation; for, $\sigma_{t}^{2}\left(v_{t}^{2}\right)$ has impact $\left(\alpha+\gamma d_{t-1}\right) \varepsilon_{t-1}^{2}((\alpha+$ $\left.\left.\gamma d_{t-1}\right) \mu_{t-1}^{2}\right)$ in addition to the previous period's variation, which means negative news have a greater impact. If $\gamma>0$, bad news from the previous period will have a greater impact in the current period than the good news in the previous period, and when $\gamma$ is not significantly different from 0 , the volatility asymmetric effect does not exist.

\subsubsection{EGARCH Model}

Although the GARCH model has a better adaptation effect for the volatility of financial assets, according to the market, futures returns often have a leverage effect, which means that when futures returns are negatively affected, they will have a greater impact than otherwise. For volatility, which also means that futures returns are not symmetrical, the GARCH model cannot explain this characteristic. [19] proposed the asymmetric EGARCH model on the basis of the GARCH model, changing its conditions to take a natural confrontation to avoid negative volatility and assumed that the impact of previous market information on volatility was increasing:

$\sigma_{t}^{2}=\omega+\frac{\alpha\left|\varepsilon_{t-1}\right|+\gamma \varepsilon_{t-1}}{\sigma_{t-1}^{2}}+\beta \sigma_{t-1}^{2}$,

$v_{t}^{2}=\omega+\frac{\alpha\left|\mu_{t-1}\right|+\gamma \mu_{t-1}}{v_{t-1}^{2}}+\beta v_{t-1}^{2}$.

If $\gamma$ equals 0 , there is asymmetry, and when $\gamma$ is significantly less than 0 and the previous period includes negative news, the fluctuation of the conditional variation is relatively higher than in a previous period with positive news. As such, $\gamma$ can be regarded as a previous news asymmetry measure of the fluctuation of the current period of variation.

\subsection{Performance Evaluation Criteria for Futures Volatility Forecast}

To measure the performance of different investors regarding futures returns fluctuations, this study sets the following loss function:

$L_{j}=\sigma_{i, j}^{2}-\hat{\sigma}_{i, j}^{2}$

where $\hat{\sigma}_{i, j}^{2}$ is the estimated value of the $i$ investor type's futures return residual variability in the $j$ model and $\sigma_{i, j}^{2}$ is the actual residual variability estimated value which is estimated in the $j$ model. The difference between the two is the loss function. $M S E$ and QLIKE are used as the evaluation criteria for the estimated performance of the model, respectively being defined as follows:

$$
\begin{aligned}
& M S E=\frac{1}{N} \sum_{k=1}^{N}\left(\sigma_{k}^{2}-\hat{\sigma}_{j, k}^{2}\right)^{2}, \\
& \text { QLIKE }=\frac{1}{N} \sum_{k=1}^{N}\left(\ln \left(\hat{\sigma}_{j, k}^{2}\right)+\sigma_{k}^{2} \hat{\sigma}_{j, k}^{-2}\right) .
\end{aligned}
$$

\section{Date Sources and Descriptive Statistics}

This research uses Taiwan's weighted stock price index and three major corporate transactions from July 1, 2010 to July 10, 2019 for a total of 2,226 trading day observations. The transaction data were obtained from the Taiwan Economic Journal (TEJ).

This study distinguishes investors' trading activities based on investor accounts, including foreign institutional, domestic institutional, and individual investors. Specifically, it determines the impacts of the three types of investors in the Taiwan index futures market on the imbalances in buy and sell orders of index futures returns and the information they have.

Table 1 shows the average daily trading volumes and market shares of the different types of investors. The main investors in the Taiwan futures market are foreign institutional investors, with transaction ratios of $58.69 \%$ and $56.44 \%$, respectively. Overall, the imbalance in the purchase and sale orders of foreign institutional investors is the smallest among the three types of investors.

Table 1. Descriptive statistics of transaction volumes for different investor types.

\begin{tabular}{lccccccc}
\hline & Total & \multicolumn{2}{c}{ Individual investors } & \multicolumn{2}{c}{$\begin{array}{c}\text { Domestic } \\
\text { institutional } \\
\text { investors }\end{array}$} & \multicolumn{2}{c}{$\begin{array}{c}\text { Foreign institutional } \\
\text { investors }\end{array}$} \\
\cline { 2 - 8 } & Position & Position & $\begin{array}{c}\text { Market } \\
\text { share }\end{array}$ & Position & $\begin{array}{c}\text { Market } \\
\text { share }\end{array}$ & Position & $\begin{array}{c}\text { Market } \\
\text { share }\end{array}$ \\
\hline Purchase & 107485 & 43133 & $40.13 \%$ & 1272 & $1.18 \%$ & 63080 & $58.69 \%$ \\
Sell & 102539 & 43390 & $42.32 \%$ & 1275 & $1.24 \%$ & 57875 & $56.44 \%$ \\
$\begin{array}{l}\text { Total } \\
\text { transactio } \\
\text { n volume } \\
\begin{array}{l}\text { Order } \\
\text { imbalance }\end{array}\end{array}$ & 210024 & 86523 & $41.20 \%$ & 2547 & $1.21 \%$ & 120955 & $57.59 \%$ \\
\hline
\end{tabular}

The data are from July 1, 2010 to July 10, 2019. The buy order value is the average of the daily sum of the multiple positions of the individual types of investors, sell order is the average of the daily sum of the short positions of the individual types of investors, total transaction volume is the average of the total daily sum of the buy and sell orders, and 
the buy and sell order imbalance is the buy order after subtracting the daily average of the sell order divided by the total transaction volume; the number of contracts is the number of contracts traded and the market share is the percentage of individual types of investor's transactions to the total market transactions. The purchase order imbalance.

To confirm whether the variables have a steady state, this paper uses two the augmented DickeyFuller (ADF) and Phillips-Perron (PP) tests. The results are shown in Table 2. Most of Taiwan's index futures trading behaviors and rates of return variables used in this paper are significant, rejecting a unit root null hypothesis. The research variables used in this paper thus do not have unit roots. Therefore, the time series data collected in this article does not have trend effects that will affect the empirical results, so as to ensure that the empirical results are not overestimated.

Table 2. Unit root tests

\begin{tabular}{llc}
\hline \multicolumn{1}{c}{ Variable } & ADF & PP \\
\hline $\begin{array}{l}\text { Individualinvestors' } \\
\text { purchase position }\end{array}$ & $-6.952(0.000)^{* * * *}$ & $-33.838(0.000)^{* * * *}$ \\
$\begin{array}{l}\text { Individual investors' sell } \\
\text { position }\end{array}$ & $-6.897(0.000)^{* * * *}$ & $-34.712(0.000)^{* * *}$ \\
$\begin{array}{l}\text { Individual investors' order } \\
\text { imbalance }\end{array}$ & $-45.040(0.000)^{* * *}$ & $-45.029(0.000)^{* * *}$ \\
\hline $\begin{array}{l}\text { Domestic institutional } \\
\text { investors' purchase } \\
\text { position }\end{array}$ & $-2.880(0.048)^{*}$ & $-21.337(0.000)^{* * *}$ \\
$\begin{array}{l}\text { Domestic institutional } \\
\text { investors' sell position }\end{array}$ & $-2.680(0.077)$ & $-21.633(0.000)^{* * * *}$ \\
$\begin{array}{l}\text { Domestic institutional } \\
\text { investors' order imbalance }\end{array}$ & $-27.662(0.000)^{* * *}$ & $-41.063(0.000)^{* * * *}$ \\
\hline $\begin{array}{l}\text { Foreign institutional } \\
\text { investors' purchase } \\
\text { position }\end{array}$ & $-4.180(0.000)^{* * * *}$ & $-13.589(0.000)^{* * * *}$ \\
$\begin{array}{l}\text { Foreign institutional } \\
\text { investors' sell position }\end{array}$ & $-4.282(0.001)^{* * *}$ & $-13.865(0.000)^{* * * *}$ \\
$\begin{array}{l}\text { Foreign institutional } \\
\text { investors' order imbalance }\end{array}$ & $-3.852(0.003)^{* * *}$ & $-58.015(0.000)^{* * * *}$ \\
\hline $\begin{array}{l}\text { Taiwan stock index futures } \\
\text { returns }\end{array}$ & $-47.523(0.000)^{* * *}$ & $-47.545(0.000)^{* * * *}$ \\
\hline
\end{tabular}

The numbers between parentheses are p-values; $* * *$ represents significance below $0.1 \%$, ** from $0.1 \%$ to $1 \%$, and $*$ from $1 \%$ to $5 \%$.

\section{Empirical Results}

The information holding characteristics of different investors are described by the information and liquidity hypotheses of [24]. Based on the former hypothesis, if investors can quickly respond to public information or have private information, they have an information advantage, and the number of buy orders, sell orders, or buy and sell order imbalances will produce constant returns on index futures. The liquidity hypothesis states that, when an investor's current and backward trading orders have a reverse relationship, that trading period has a temporary impact on futures returns fluctuations.

We use the $\operatorname{GARCH}(1,1)$, $\operatorname{TGARCH}(1,1)$, and EGARCH(1,1) models to verify the impact of different investor trading behaviors on the fluctuation of index futures returns and evaluate the characteristics of the information held by each investor type.

\subsection{GARCH(1,1) Results}

The top half of Table 3 shows the results of the current and delayed futures buy and sell orders on the rate of return and the bottom half shows the results using $\operatorname{GARCH}(1,1)$. The futures return rate is subject to fluctuations in the number of buy and sell orders. Regardless of the type of investor, the number of buy orders in the current period has a positive and significant effect on futures returns, while the number of sell orders has a negative and significant effect on futures returns. That is, the current buying or selling order transaction behavior will affect futures returns.

Table 3. GARCH $(1,1)$ results for the effect of the number of buy and sell orders on the futures returns

\begin{tabular}{|c|c|c|c|c|c|c|}
\hline & \multicolumn{2}{|c|}{ Individual investors } & \multicolumn{2}{|c|}{$\begin{array}{c}\text { Domestic institutional } \\
\text { investors }\end{array}$} & \multicolumn{2}{|c|}{$\begin{array}{c}\text { Foreign institutional } \\
\text { investors }\end{array}$} \\
\hline & coefficient & $\mathrm{t}$ value & coefficient & $\mathrm{t}$ value & coefficient & $\mathrm{t}$ value \\
\hline Cons. & 13.521 & $2.845^{* * *}$ & 5.884 & $3.746^{* * * * *}$ & 20.125 & 8.793 **** \\
\hline$B_{i, t}$ & 0.008 & $26.845^{* * * *}$ & 0.072 & $41.643 * * *$ & 0.007 & $37.441^{* * * *}$ \\
\hline$B_{i, t-1}$ & 0.001 & 0.252 & -0.014 & $-5.717 * * *$ & 0.004 & $15.515^{* * *}$ \\
\hline$S_{i, t}$ & -0.009 & $-31.393 * * *$ & -0.073 & $-41.823^{* * *}$ & -0.008 & $-44.589^{* * * *}$ \\
\hline$S_{i, t-1}$ & 0.001 & 1.011 & 0.013 & $5.550^{* * * *}$ & -0.003 & $-13.290^{* * * *}$ \\
\hline \multicolumn{7}{|c|}{ Variation equation $\left(\sigma_{t}^{2}=\omega+\alpha \varepsilon_{t-1}^{2}+\beta \sigma_{t-1}^{2},\right)$} \\
\hline$\omega$ & 153.164 & $6.552^{* * * *}$ & 98.348 & $5.737^{* * * *}$ & 77.531 & $4.787^{* * * * *}$ \\
\hline$\alpha$ & 0.114 & $13.928 * * *$ & 0.076 & $12.266 * * *$ & 0.058 & $9.236 * * *$ \\
\hline$\beta$ & 0.870 & $93.783^{* * *}$ & 0.908 & $104.754 * * *$ & 0.928 & 118.602 **** \\
\hline $\begin{array}{l}\text { Adj. } \\
R^{2}\end{array}$ & \multicolumn{2}{|c|}{$9.218 \%$} & \multicolumn{2}{|c|}{$23.684 \%$} & \multicolumn{2}{|c|}{$35.776 \%$} \\
\hline Obs. & \multicolumn{2}{|c|}{2226} & \multicolumn{2}{|c|}{2226} & \multicolumn{2}{|c|}{2226} \\
\hline
\end{tabular}

The buying and selling orders of different investors in the lagging period, the number of lagging buying and selling orders of domestic institutional investors and foreign institutional investors, and the current rate of return on futures are mostly significant, which support the liquidity hypothesis. This means that domestic institutional and foreign institutional investors are more likely to place orders due to liquidity and speculative factors; however, the coefficient of the lagging period of individual investors is not significant, meaning the current price impact will not be deferred. This is in line with the expectations of the information hypothesis, meaning that the response of individual investors to market information has a constant impact on market returns. $\operatorname{GARCH}(1,1)$ measures the futures rate of return as a result of fluctuations in the number of buy and sell orders. The results in the lower part of Table 3 show that the coefficients have significant and positive effects, meaning the number 
of buy and sell orders and the fluctuation of the futures return rate of the current period will be affected by past information regardless of the type of investor.

The estimated results of the impact of different types of investors' futures order imbalances on the rate of return are shown in the upper part of Table 4. Under $\operatorname{GARCH}(1,1)$, the fluctuations in the futures returns of the different types of investors are affected by order imbalances. The higher the imbalance in the current purchase and sale orders of all investors, the greater the impact on the market price is. The results of the lagging period show that only the coefficient on foreign institutional investors is negative and significant for the current index futures return, which means foreign investors are more likely to trade speculatively. Table 4 shows that $\alpha$ and $\beta$ have significant and positive effects for various types of investors. The number of buy and sell orders for current futures return fluctuations will be affected by past information.

Table 4. GARCH(1,1) results for the impact of the order imbalances in the buy and sale of different types of investors on futures returns.

\begin{tabular}{|c|c|c|c|c|c|c|}
\hline & \multicolumn{2}{|c|}{ Individual investors } & \multicolumn{2}{|c|}{$\begin{array}{c}\text { Domestic institutional } \\
\text { investors }\end{array}$} & \multicolumn{2}{|c|}{$\begin{array}{l}\text { Foreign institutional } \\
\text { investors }\end{array}$} \\
\hline & coefficient & $\mathrm{t}$ value & coefficient & $\mathrm{t}$ value & coefficient & $t$ value \\
\hline Cons. & 9.370 & 6.596 **** & 4.743 & $3.451^{* * * * *}$ & 7.310 & $5.002^{* * * *}$ \\
\hline$E_{i, t}$ & 27.288 & $32.288^{* * * *}$ & 15.739 & $49.932^{* * * *}$ & 3.096 & $16.127^{* * * *}$ \\
\hline$E_{i, t-1}$ & -0.106 & -0.101 & -0.947 & -1.040 & 0.887 & $-3.716^{* * * *}$ \\
\hline \multicolumn{7}{|c|}{ Variation equation $\left(v_{t}^{2}=\omega+\alpha \mu_{t-1}^{2}+\beta v_{t-1 .}^{2},\right)$} \\
\hline$\omega$ & 164.288 & $6.938^{* * * *}$ & 108.494 & $5.369^{* * * *}$ & 223.552 & $6.509^{* * * *}$ \\
\hline$\alpha$ & 0.123 & $17.809^{* * *}$ & 0.084 & $11.285^{* * *}$ & 0.103 & $15.449^{* * *}$ \\
\hline$\beta$ & 0.862 & $102.377 * * *$ & 0.899 & $96.144 * * *$ & 0.868 & $84.218^{* * * *}$ \\
\hline $\begin{array}{c}\text { Adj. } \\
R^{2}\end{array}$ & \multicolumn{2}{|c|}{$11.730 \%$} & \multicolumn{2}{|c|}{$16.773 \%$} & \multicolumn{2}{|c|}{$34.703 \%$} \\
\hline Obs. & \multicolumn{2}{|c|}{2226} & \multicolumn{2}{|c|}{2226} & \multicolumn{2}{|c|}{2226} \\
\hline
\end{tabular}

\subsection{TGARCH(1,1) Results}

From the upper part of Table 5, regardless of the type of investor, the number of current buy orders has a significant positive impact on futures returns, while the number of sell orders during the current period has a negative significant effect on futures returns. The coefficient on the lagging period is significant. The number of lagging buy and sell orders and the current futures return of domestic institutional and foreign institutional investors are significant, supporting the liquidity hypothesis. The subsequent coefficients are not significant, supporting the information hypothesis.

$\operatorname{TGARCH}(1,1)$ measures the futures return rate as fluctuated by the number of buy and sell orders. It is shown at the bottom of Table 5. Since the coefficient of $\gamma$ shows a significant and positive effect, regardless of investor type, for negative news in a period, the number of buy and sell orders will have a sharper fluctuation on the current futures return. However, in the variation equation of foreign institutional investors, $\alpha$ is not significant, which means foreign institutional investors encountered negative news in the previous period; therefore, the current trading behavior has a lower impact on futures returns.

Table 5. TGARCH $(1,1)$ results for the effect of the number of buy and sell orders on the futures returns of different investor types.

\begin{tabular}{|c|c|c|c|c|c|c|}
\hline & \multicolumn{2}{|c|}{ Individual investors } & \multicolumn{2}{|c|}{$\begin{array}{c}\text { Domestic institutional } \\
\text { investors }\end{array}$} & \multicolumn{2}{|c|}{$\begin{array}{c}\text { Foreign institutional } \\
\text { investors }\end{array}$} \\
\hline & coefficient & $\mathrm{t}$ value & coefficient & $\mathrm{t}$ value & coefficient & $\mathrm{t}$ value \\
\hline Cons. & 12.201 & $2.805 * *$ & 5.202 & $3.261^{* * *}$ & 8.472 & $4.385 * * *$ \\
\hline$B_{i, t}$ & 0.007 & $24.960 * * *$ & 0.071 & $39.447 * * * *$ & 0.007 & $33.013^{* * *}$ \\
\hline$B_{i, t-1}$ & -0.001 & -0.596 & -0.015 & $-6.214 * * *$ & 0.002 & $10.802 * * *$ \\
\hline$S_{i, t}$ & -0.008 & $-29.512 * * *$ & -0.0713 & $-40.083^{* * *}$ & -0.008 & $-37.606^{* * * *}$ \\
\hline$S_{i, t-1}$ & 0.001 & 2.056 & 0.0148 & $6.079 * * *$ & -0.002 & $-7.823 * * *$ \\
\hline \multicolumn{7}{|c|}{ Variation equation $\left(\sigma_{t}^{2}=\omega+\left(\alpha+\gamma d_{t-1}\right) \varepsilon_{t-1}^{2}+\beta \sigma_{t-1}^{2},\right)$} \\
\hline$\omega$ & 191.479 & $7.571^{* * * * *}$ & 139.861 & $6.455^{* * * *}$ & 555.601 & $12.716^{* * * *}$ \\
\hline$\alpha$ & 0.060 & $6.045 * * *$ & 0.036 & $3.706^{* * * *}$ & -0.015 & -1.432 \\
\hline$\beta$ & 0.122 & $9.406 * * *$ & 0.081 & $7.262 * * *$ & 0.363 & $11.519^{* * * *}$ \\
\hline $\begin{array}{c}\text { Adj. } \\
R^{2}\end{array}$ & \multicolumn{2}{|c|}{$11.369 \%$} & \multicolumn{2}{|c|}{$23.751 \%$} & \multicolumn{2}{|c|}{$30.246 \%$} \\
\hline Obs. & \multicolumn{2}{|c|}{2226} & \multicolumn{2}{|c|}{2226} & \multicolumn{2}{|c|}{2226} \\
\hline
\end{tabular}

The effect of various types of investor imbalances in futures orders on returns affects the return rate. The results are shown in the upper part of Table 6, showing that the higher the imbalance in the current purchase and sale orders of the various types of investors, the greater the impact on the market price. Under the $\operatorname{TGARCH}(1,1)$ in the lagging period, domestic and foreign investors' coefficients are inverse and significant for the current index futures return, which means these two types of investors are more likely to trade speculatively.

Table 6. TGARCH $(1,1)$ results for the impact of order imbalances in the buy and sale of different investor types on futures returns.

\begin{tabular}{|c|c|c|c|c|c|c|}
\hline & \multicolumn{2}{|c|}{ Individual investors } & \multicolumn{2}{|c|}{$\begin{array}{c}\text { Domestic institutional } \\
\text { investors }\end{array}$} & \multicolumn{2}{|c|}{$\begin{array}{c}\text { Foreign institutional } \\
\text { investors }\end{array}$} \\
\hline & coefficient & $\mathrm{t}$ value & coefficient & $\mathrm{t}$ value & coefficient & $\mathrm{t}$ value \\
\hline Cons. & 7.658 & $5.213^{* * * *}$ & 4.085 & $2.965^{* *}$ & 4.679 & $3.229^{* *}$ \\
\hline$E_{i, t}$ & 25.063 & $30.640 * * *$ & 15.751 & $47.926^{* * *}$ & 3.156 & $15.755^{* * * *}$ \\
\hline$E_{i, t-1}$ & -1.113 & -1.103 & -3.286 & $-5.737 * * *$ & 0.864 & $-3.626 * * * *$ \\
\hline \multicolumn{7}{|c|}{ Variation equation $\left(v_{t}^{2}=\omega+\left(\alpha+\gamma d_{t-1}\right) \mu_{t-1}^{2}+\beta v_{t-1}^{2},\right)$} \\
\hline$\omega$ & 218.750 & $8.020^{* * * *}$ & 148.132 & 6.996 **** & 374.073 & $10.102^{* * * *}$ \\
\hline$\alpha$ & 0.055 & $4.894 * * *$ & 0.031 & $3.409^{* * * *}$ & -0.019 & -2.199 \\
\hline$\beta$ & 0.124 & $10.686^{* * * *}$ & 0.082 & $8.069^{* * * *}$ & 0.188 & $17.668^{* * * *}$ \\
\hline $\begin{array}{c}\text { Adj. } \\
R^{2}\end{array}$ & \multicolumn{2}{|c|}{$12.682 \%$} & \multicolumn{2}{|c|}{$18.763 \%$} & \multicolumn{2}{|c|}{$3.826 \%$} \\
\hline Obs. & \multicolumn{2}{|c|}{2226} & \multicolumn{2}{|c|}{2226} & \multicolumn{2}{|c|}{2226} \\
\hline
\end{tabular}
and $1 \%$ levels, respectively.

At the bottom of Table 6 , the $\operatorname{TGARCH}(1,1)$ model measures the futures return rate as a result of fluctuations in the number of imbalances in the buy and sell orders. $\gamma$ all show significant and positive 
effects for the various types of investors. When negative news exist in the current period, the unbalanced trading behavior of the purchase and sale order will cause more severe fluctuations in the current futures return. In Table 6, each investor's futures returns variation equation is estimated. The results for foreign institutional investors are as in Table 4. The coefficient of variation, is not significant. Therefore, foreign institutional investors' futures volatility is lower when faced with negative news compared to other investors.

\subsection{EGARCH(1,1) Results}

The results of the $\operatorname{EGARCH}(1,1)$ are presented in Tables 7 and 8. From the upper part of Table 7, the number of purchase orders for the various types of investors has a positive and significant effect on futures returns. While the number of sell orders in the current period has the opposite effect, in the lagging period, the number of purchase transactions by individual investors has no significant effect on the futures return of the current period, supporting the information hypothesis. All values are significant for the current futures returns and tend to support the liquidity hypothesis. In the lower part of Table 7, EGARCH $(1,1)$ measures the return on futures as a result of fluctuations in the number of buy and sell orders. $\alpha$ is positive and $\gamma$ is negatively significant. This means that, regardless of the type of investor, negative news in the previous period will have a more dramatic fluctuation in the futures return.

Table 7. EGARCH $(1,1)$ results for the effect of the number of buy and sell orders on the futures returns of different investor types.

\begin{tabular}{|c|c|c|c|c|c|c|}
\hline & \multicolumn{2}{|c|}{ Individual investors } & \multicolumn{2}{|c|}{$\begin{array}{c}\text { Domestic institutional } \\
\text { investors } \\
\end{array}$} & \multicolumn{2}{|c|}{$\begin{array}{c}\text { Foreign institutional } \\
\text { investors }\end{array}$} \\
\hline & coefficient & $\mathrm{t}$ value & coefficient & $t$ value & coefficient & $t$ value \\
\hline Cons. & 11.320 & $2.917 * *$ & 5.072 & $3.248^{* *}$ & 6.897 & $3.875 * * *$ \\
\hline$B_{i, t}$ & 0.007 & $24.623 * * *$ & 0.070 & $39.289^{* * * *}$ & 0.007 & $34.085^{* * * *}$ \\
\hline$B_{i, t-1}$ & 0.001 & -0.534 & -0.015 & $-6.491 * * * *$ & 0.002 & $9.987 * * *$ \\
\hline$S_{i, t}$ & -0.008 & $-28.959 * * * *$ & -0.0713 & $-39.510 * * *$ & -0.008 & $-38.978 * * *$ \\
\hline$S_{i, t-1}$ & 0.001 & $2.357 *$ & 0.0148 & $6.289 * * *$ & -0.002 & $-7.782 * * * *$ \\
\hline \multicolumn{7}{|c|}{ Variation equation $\left(\sigma_{t}^{2}=\omega+\frac{\alpha\left|\varepsilon_{t-1}\right|+\gamma \varepsilon_{t-1}}{\sigma_{t-1}^{2}}+\beta \sigma_{t-1}^{2}\right)$} \\
\hline$\omega$ & 0.210 & $4.821^{* * * *}$ & 0.117 & $3.735^{* * * *}$ & 0.452 & $7.756^{* * * *}$ \\
\hline$\alpha$ & 0.216 & $13.384 * * *$ & 0.133 & $10.846^{* * * *}$ & 0.177 & $9.155^{* * * *}$ \\
\hline$\beta$ & -0.083 & $-9.264 * * *$ & -0.064 & $-9.250 * * * *$ & -0.158 & $-13.442 * * * *$ \\
\hline $\begin{array}{l}\text { Adj. } \\
R^{2}\end{array}$ & \multicolumn{2}{|c|}{$12.157 \%$} & \multicolumn{2}{|c|}{$23.953 \%$} & \multicolumn{2}{|c|}{$30.702 \%$} \\
\hline Obs. & \multicolumn{2}{|c|}{2226} & \multicolumn{2}{|c|}{2226} & \multicolumn{2}{|c|}{2226} \\
\hline
\end{tabular}

The impacts of the various types of investor imbalances in futures purchase and sale orders on the return rate are shown in the upper part of Table 8. From the $\operatorname{TGARCH}(1,1)$ and $\operatorname{GARCH}(1,1)$ estimation results, current trading affects futures returns imbalances. The higher the imbalance in the current purchase and sale orders of the various types of investors, the greater the impact on the market price is. According to the $\operatorname{EGARCH}(1,1)$ estimation results for the previous period, domestic and foreign investors' lagging period coefficients are negative and significant for current index futures returns, supporting speculative trading behavior.

EGARCH $(1,1)$ measures the return on futures as a result of the fluctuation of the purchase order imbalance at the bottom of Table 8 . According to the estimation results of the variance equations of individual and domestic institutional investors, $\alpha$ is positive and significant, as is $\gamma$. Both show significant and negative effects; in the estimation results of the variation number equations of foreign institutional investors, $\alpha$ is not significant and $\gamma$ shows significant and negative effects, indicating the foreign institutional investors encountered negative news in the previous period. The imbalance of the purchase and sale order has a lower impact on the futures trading behavior than the other two.

Table 8. EGARCH $(1,1)$ results for the impact of order imbalances in the buy and sale of different investor types on futures returns.

\begin{tabular}{|c|c|c|c|c|c|c|}
\hline & \multicolumn{2}{|c|}{ Individual investors } & \multicolumn{2}{|c|}{$\begin{array}{l}\text { Domestic institutional } \\
\text { investors }\end{array}$} & \multicolumn{2}{|c|}{$\begin{array}{c}\begin{array}{c}\text { Foreign institutional } \\
\text { investors }\end{array} \\
\end{array}$} \\
\hline & coefficient & $\mathrm{t}$ value & coefficient & $t$ value & coefficient & $t$ value \\
\hline Cons. & 6.740 & $4.666^{* * * *}$ & 3.703 & $2.736^{* * *}$ & 4.099 & $2.854 * *$ \\
\hline$E_{i, t}$ & 25.237 & $31.092 * * *$ & 15.715 & $47.212^{* * * *}$ & 3.158 & $16.185^{* * * *}$ \\
\hline$E_{i, t-1}$ & -0.805 & -0.819 & -3.246 & $-5.824 * * *$ & 0.888 & $-3.816 * * *$ \\
\hline \multicolumn{7}{|c|}{ Variation equation $\left(v_{t}^{2}=\omega+\frac{\alpha\left|\mu_{t-1}\right|+\gamma \mu_{t-1}}{v_{t-1}^{2}}+\beta v_{t-1}^{2}\right)$} \\
\hline$\omega$ & 0.262 & $5.928 * * *$ & 0.108 & $4.040^{* * * *}$ & 0.499 & $8.943 * * *$ \\
\hline$\alpha$ & 0.215 & $14.775^{* * * *}$ & 0.123 & $9.821 * * *$ & 0.108 & 7.199 \\
\hline$\beta$ & -0.091 & $-11.883^{* * * *}$ & -0.064 & $-9.593^{* * * *}$ & -0.160 & $-18.728^{* * * * *}$ \\
\hline $\begin{array}{c}\text { Adj. } \\
R^{2}\end{array}$ & \multicolumn{2}{|c|}{$12.648 \%$} & \multicolumn{2}{|c|}{$18.616 \%$} & \multicolumn{2}{|c|}{$3.749 \%$} \\
\hline Obs. & \multicolumn{2}{|c|}{2226} & \multicolumn{2}{|c|}{2226} & \multicolumn{2}{|c|}{2226} \\
\hline
\end{tabular}

\subsection{Model Results Testing}

We using $M S E$ and QLIKE to detect different investors' volatility performances in futures returns captured under the different volatility estimation models. According to the previous section, the lowest loss function shows the best estimated performance. Therefore, the estimated values in Tables 9 and 10 show the best performance in the rank column (RANK) as 1 . The larger the values in the RANK column, the worse the estimation result of the corresponding volatility prediction model.

Table 9. MSE and QLIKE results for the volatility of the number of buy and sell orders on the return of index futures.

\begin{tabular}{|c|c|c|c|c|c|}
\hline \multicolumn{2}{|c|}{ Individual investors } & \multicolumn{2}{|c|}{$\begin{array}{l}\text { Domestic institutional } \\
\text { investors }\end{array}$} & \multicolumn{2}{|c|}{$\begin{array}{l}\text { Foreign institutional } \\
\text { investors }\end{array}$} \\
\hline MSE & RANK & MSE & RANK & MSE & RANK \\
\hline
\end{tabular}




\begin{tabular}{|c|c|c|c|c|c|c|}
\hline \multirow[b]{2}{*}{$\operatorname{GARCH}(1,1)$} & \multirow[b]{2}{*}{8.510} & & \multirow[b]{2}{*}{572.845} & & \multirow[b]{2}{*}{2023.280} & \\
\hline & & 3 & & 3 & & 1 \\
\hline $\operatorname{TGARCH}(1,1)$ & 6.027 & 2 & 474.120 & 1 & 2207.823 & 2 \\
\hline \multirow[t]{2}{*}{$\operatorname{EGARCH}(1,1)$} & 6.006 & 1 & 496.752 & 2 & 2927.999 & 3 \\
\hline & QLIKE & RANK & QLIKE & RANK & QLIKE & RANK \\
\hline $\operatorname{GARCH}(1,1)$ & 5.748 & 3 & 6.259 & 3 & 6.896 & 1 \\
\hline $\operatorname{TGARCH}(1,1)$ & 5.414 & 2 & 6.156 & 1 & 7.771 & 2 \\
\hline $\operatorname{EGARCH}(1,1)$ & 5.283 & 1 & 6.173 & 2 & 9.493 & 3 \\
\hline
\end{tabular}

Table 9 estimates the fluctuations in futures returns from the number of buy and sell orders by the $\operatorname{GARCH}(1,1), \quad \operatorname{TGARCH}(1,1), \quad$ and EGARCH(1,1) models. EGARCH(1,1) has the best estimation results for individual investors; $\operatorname{TGARCH}(1,1)$ for domestic institutions, and $\operatorname{GARCH}(1,1)$ the best overall estimation results. This shows that investors' estimation of futures returns volatilities can require different models.Table 10 estimates the impact of the imbalance behavior of the purchase and sales order on the fluctuation of the index futures by different variant equations of MSE and QLIKE. All three types of investors use $\operatorname{EGARCH}(1,1)$ to estimate the best results. This means that the effect of the imbalance of the purchase and sale order on the volatility of the index futures returns is asymmetric, that is, when the current period includes bad news, the imbalance of the buy and sell orders will have a greater impact on futures returns than otherwise.

Table 10. MSE and QLIKE results for the volatility of returns on index futures for index futures.

\begin{tabular}{lcccccc}
\hline & \multicolumn{2}{c}{ Individual investors } & \multicolumn{2}{c}{$\begin{array}{c}\text { Domestic institutional } \\
\text { investors }\end{array}$} & \multicolumn{2}{c}{$\begin{array}{c}\text { Foreign institutional } \\
\text { investors }\end{array}$} \\
\cline { 2 - 7 } & MSE & RANK & MSE & RANK & MSE & RANK \\
\hline $\operatorname{GARCH}(1,1)$ & 384.691 & 3 & 230.325 & 3 & 56.144 & 3 \\
$\operatorname{TGARCH}(1,1)$ & 325.510 & 2 & 200.142 & 2 & 25.742 & 2 \\
$\operatorname{EGARCH}(1,1)$ & 296.656 & 1 & 195.148 & 1 & 19.856 & 1 \\
\hline & QLIKE & RANK & QLIKE & RANK & QLIKE & RANK \\
\hline $\operatorname{GARCH}(1,1)$ & 407.487 & 3 & 5.999 & 3 & 19.709 & 2 \\
$\operatorname{TGARCH}(1,1)$ & 318.956 & 2 & 5.802 & 2 & 23.889 & 3 \\
$\operatorname{EGARCH}(1,1)$ & 317.476 & 1 & 5.793 & 1 & 11.162 & 1 \\
\hline
\end{tabular}

\section{Conclusion}

This article considers different types of investors to test the price impact of Taiwan index futures market trading activities and explores the information role of these different types of investors. When the market is fully efficient and information is publicly available, the futures market should exhibit market depth and liquidity; therefore, index futures trading should not have price shocks and the information roles of different investors should be similar. However, by testing the information and liquidity hypotheses of [24], the trading volume of different investors in the index futures market affects futures returns.

Further, this paper uses empirical models of error fluctuation variations, namely $\operatorname{GARCH}(1,1)$, $\operatorname{TGARCH}(1,1)$, and $\operatorname{EGARCH}(1,1)$ to evaluate the impact of information conditions of different investors on the fluctuation of asset prices. Additionally, an empirical model for evaluating the price fluctuations of different products through loss functions is used to estimate performance.

According to [24], individual investors are more likely to meet the information hypothesis, while domestic institutional and foreign institutional investors are more inclined to follow the liquidity hypothesis. As such, using $\operatorname{TGARCH}(1,1)$ and $\operatorname{EGARCH}(1,1)$, when there are negative news in the current period, the trading behavior of foreign institutional investors is compared with the other two types of investors. The impact on the index futures returns in the current period is small, representing the ability of foreign institutional investors to quickly respond to negative news and form an information advantage.

According to the MSE and QLIKE loss functions, we examine the variation equations of the futures return fluctuations for different investor transactions. We obtain the effects of futures buy and sell orders of different investors on the futures return, finding that individual investors should use $\operatorname{EGARCH}(1,1)$, domestic institutional investors $\operatorname{TGARCH}(1,1)$, and foreign institutional investors $\operatorname{GARCH}(1,1)$. Regardless of the investor type, the imbalance of buy and sell orders is suitable for the fluctuation of futures returns and the use of $\operatorname{EGARCH}(1,1)$. $T$ This article confirms the views of $[2,17]$ that when investors have more information endowments, they can avoid investment losses caused by bad news on asset prices. Therefore, futures investors will be affected by information restrictions. Caused to be unable to make appropriate trading behavior patterns completely rationally.

Considering the purchase order transaction behavior of foreign institutional investors, the variability of the futures return volatility estimated by $\operatorname{TGARCH}(1,1)$ and $\operatorname{EGARCH}(1,1)$ is lower than that of other investors and the loss function is asymmetric. The GARCH $(1,1)$ model of the shock of volatility obtains better estimation results. In the Taiwan index futures market, foreign institutional investors have more information than domestic and 
individual investors, meaning endowment can reduce investment losses caused by negative news. In the future studies, the volatility trends of futures returns or other investment targets need to consider investor information endowment, investment preferences, and other relevant investment-related characteristics to find a suitable volatility estimation model and clarify the impact path. However, because Taiwan is a small open country, the fluctuation of the investment market is easily affected by the economic situation of other countries, especially over our analysis period, which included a period of Sino-US trade wrestling, which interfered with the fluctuation trend of the investment targets. Researchers should also consider other foreign economic factors to ensure the robustness of their results.

\section{References:}

[1] Antoniou, A., and P. Holmes, P., Futures trading, information and spot price volatility: Evidence for the FTSE-100 stock index futures contract using GARCH, Journal of Banking and Finance, Vol.19, 1995, pp.117-29.

[2] Arunsingkarat, S., Costa, R., Misran, M., and Phewchean, N. Option pricing under GARCH models applied to the SET50 index of Thailand. WSEAS Transactions on Mathematics, 20, 2021 pp.112-121.

[3] Antoniou, A., G. Koutmos, and A. Pericli, Index futures and positive feedback trading: Evidence from major stock exchanges. Journal of Empirical Finance, Vol.12, No.5, 2005, pp.219-38.

[4] Anand, A., and S. Chakravarty, Stealth trading in options markets. Journal of Financial and Quantitative Analysis, Vol.42, No.1, 2007, pp.167-87..

[5] Bagehot, W., The only game in town. Financial Analysts Journal, Vol.27, No.2,1971, pp.1214.

[6] Brennan, M. J., and A. Subrahmanyam, Market microstructure and asset pricing: On the compensation for illiquidity in stock returns. Journal of Financial Economics, Vol.41, No.3, 1996, pp.441-464.

[7] Copeland, T. E., and D. Galai, Information effects on the bid-ask spread. The Journal of Finance, Vol.38, No.5, 1983, pp.1457-1469.

[8] Duan, C. W., and J. C. Lin, The predictive power of volatility models: Evidence from the ETF Market. Investment Management and Financial Innovations, Vol.11, No.2, 2014, pp. 100-110.
[9] Franses, P. H., Recent advances in modelling seasonality. Journal of Economic Surveys, Vol.10, No.3, 1996, pp. 299-345.

[10] Glosten, L. R., and P. R. Milgrom, Bid, ask and transaction prices in a specialist market with heterogeneously informed traders. Journal of Financial Economics, Vol.14, No.1, 1985, pp.71-100.

[11] Gokcan, S., Forecasting volatility of emerging stock markets: Linear versus non- linear GARCH models. Journal of Forecasting, Vol.19, No.6, 2000, pp. 499-504.

[12] González-Rivera, G., T. H Lee, and S. Mishra., Forecasting volatility: A reality check based on option pricing, utility function, value-at-risk, and predictive likelihood. International Journal of Forecasting, Vol.20, No.4, 2004, pp. 629645.

[13] Guijarro, F., Moya-Clemente, I., and Saleemi, J. Liquidity risk and investors' mood: linking the financial market liquidity to sentiment analysis through twitter in the S\&P500 index. Sustainability, 11(24), 2019.pp.394-405.

[14] Huang, R. D., and H. R. Stoll, The components of the bid-ask spread: A general approach, Review of Financial Studies, Vol.10, No.4, 1997, pp. 995-1034.

[15] Hsieh, W. L., C. S. Lee, and S. F. Yuan, Price discovery in the option markets: An application of put-call parity. Journal of Futures Markets, Vol.28, No.4, 2008, pp. 354-375.

[16] .Hong, H., and J. C. Stein, A unified theory of underreaction, momentum trading, and overreaction in asset markets. The Journal of Finance, Vol.54, No.6, 1999, pp. 2143-2184.

[17] Kuo, W. H., S. L. Chung, and C. Y. Chang, The impacts of individual and institutional trading on futures returns and volatility: Evidence from emerging index futures markets. Journal of Futures Markets, Vol.35, No.3, 2015, pp. 222-244.

[18] Lin, Forecasting the volatility of stock index returns. Graduate Institute of Banking and Finance, Tamkang University, Taiwan., 2008.

[19] Nelson, D. B., Conditional heteroskedasticity in asset returns: A new approach. Econometrica: Journal of the Econometric Society, Vol.59, No.2, 1991, pp. 347-370.

[20] Pereira, G. M. L., Camilo-da-Silva, E., and Barbedo, C. H. D. S. Trading Imbalance, Liquidity and Stock Returns: Evidence from Brazil. Latin American Business Review, 21(2), 2020, pp.173-195. 
[21] Ryu, D., and Yang, H. Intraday option price changes and net buying pressure. Applied Economics Letters, 2020, pp.1-6.

[22] Roncalli, T. Handbook of Financial Risk Management. CRC Press. 2020.

[23] Stoll, H. R., Presidential address: Friction. The Journal of Finance, Vol.55, No.4, 2000, pp. 1479-1514.

[24] Schlag, C., and H. Stoll, Price impacts of options volume. Journal of Financial Markets, Vol.8, No.1, 2005, pp. 69-87.

[25] Sadka, R., Momentum and post-earningsannouncement drift anomalies: The role of liquidity risk. Journal of Financial Economics, Vol.80, No.2, 2006, pp. 309-349.
Contribution of Individual Authors to the Creation of a Scientific Article (Ghostwriting Policy)

The authors contributed equally to this paper. ChunNan Chen has organized and executed the experiments of Section 1, Section 2 and Section 5. Chen-Cheng Chien was responsible for the Statistics and executed the experiments of Section 3, and Section 4.

\section{Sources of Funding for Research Presented} in a Scientific Article or Scientific Article Itself

This article is not subsidized by any research institution or organization, it is purely an academic research article from National Taiwan University of Science and Technology in Taiwan.

Creative Commons Attribution License 4.0 (Attribution 4.0 International, CC BY 4.0)

This article is published under the terms of the Creative Commons Attribution License 4.0 https://creativecommons.org/licenses/by/4.0/deed.en _US 